\title{
X. Problems with Application of International Law in Ukraine: Theoretical and Practical Issues
}

Taras Tsymbrivskyy*

\section{The Lack of Proper Definition of the Status of International Law in the Law of Ukraine}

The first legislative acts related to the application of international law were adopted in Ukraine in the mid-1990s. Amongst others the 1990 Declaration of State Sovereignty of Ukraine ${ }^{1}$ belongs to the group of acts (non-obligatory by their nature) to initially define the relationship between national law and international law. Provisions of the Declaration, in particular its Chapter X "International relations", accept the supremacy of generally recognized principles of international law:" "The Ukrainian Soviet Socialist Republic recognizes the prevalence of gener-

* Dr iur., Associate Professor, Chair of Theory of Law and Human Rights, Ukrainian Catholic University, Lviv, Ukraine.

1 О. Барабаш, Декларація про державний суверенітет України. Історія прийняття, документи, свідчення (Рута 2010) [Barabash O., Declaration of state sovereignty of Ukraine. History of adoption, documents, testimonies (Ruta 2010)].

2 О. Буткевич, 'Конституційна реформа та проблеми міжнародної договірної практики України' (2014) 3 Український часопис міжнародного права, p. 42 [O. Butkevych, 'Constitutional reform and problems of Ukraine's treaty practice' (2014) 3 Ukrainian Journal of International Law 42]. 
al human values over class values and the priority of generally accepted standards of international law over the standards of the domestic law."3 Implicitly this pledge pertains also to the sphere of foreign policy (thus omitting domestic policy).

The Declaration of State Sovereignty of Ukraine served as a foundation for the elaboration and adoption of further legal rules, including the relevant provisions of the Constitution. ${ }^{4}$ The 1991 concept for the new Ukrainian constitution adopted by the Parliament, reflected the similar approach towards international law. It implied Ukraine's prioritizing international law (through its generally recognized principles) within the process of inter-State relations and communication. Its concept was embodied by the parliament's decision of 1993 "The main directions of foreign policy of Ukraine", ${ }^{5}$ which emphasized that Ukraine's foreign policy is governed by international law norms which are superior to national law.

The extensive formalization of the rules of application of international law in the domestic legal system commenced with the adoption in 1991 of a Special law on the application of international treaties on the territory of Ukraine. ${ }^{6}$ Its provisions, for the first time in Ukrainian legal history, expressly determined the relation between international and national law recognizing that in order to ensure inviolability of human rights and freedoms "international agreements concluded and ratified by Ukraine constitute an integral part of national legislation." Thus the law foresees commitment to apply international law in the domestic legal system of Ukraine.

The analogous clauses may be found in the 1993 Law on international treaties of Ukraine, ${ }^{7}$ and concretely in its Art. 17(1). However, the latter bears a resemblance to the 1991 Law on the application of International Treaties on the territory of Ukraine. At the same time, it had a more comprehensive effect on the application of international law in the Ukrainian legal order. Pursuant to Art. 17(2) of the 1993 Law on international treaties, norms of the ratified treaty are applicable in case it foresees other rules than national legislation. Generally, such law provisions clearly refer only to the international treaties, which were consented to

3 Declaration on State Sovereignty of Ukraine, <http://zakon2.rada.gov.ua/laws/show/55-12> (access: 24 July 2016).

4 Regrettably the 1991 Declaration of independence of Ukraine, in essence, encompasses solely clauses with reference to the validity of the constitution and laws within the territory of Ukraine and disregards utterly applicability of international law. Although the 1991 Law on succession of Ukraine emphasizes Ukraine's commitment to international obligations stemming from the treaties concluded by Ukrainian Soviet Socialist Republic (USSR) before its proclamation of independence and consequently declares itself as a successor of international rights and duties of USSR which do not contradict the constitution of Ukraine.

5 The decision lost its force in 2010 due to the adoption of the Law on principles of internal and foreign policy of Ukraine (2010).

6 The Law lost its force in 2004 upon the entry into force of the Law on International treaties of Ukraine (2004).

7 The Law lost its force in 2004 upon the entry into force of the Law on International treaties of Ukraine (2004). 
by the parliament. The subsequent 2014 Law on international treaties of Ukraine followed the same pattern. Art. 19(2) reads: "international treaty of Ukraine, consented by the parliament, provided it sets out other rules than national legislation, ought to be applied."

As it was previously noted, the domestic law before the adoption of the Constitution in 1996 distinguished the application of international law in foreign and internal policies. From this point of view, the 1996 Constitution of Ukraine did not bring about any breakthrough, since it just reiterated and strengthened preceding law provisions. In this context, two cornerstone provisions of the Constitution referring to international law are worth mentioning.

Under Art. 9 international treaties in force, consented to by the parliament, are recognized as a part of Ukraine's national legislation. "International treaties in force, consented by the Verkhovna Rada of Ukraine as binding shall be an integral part of the national legislation of Ukraine. Conclusion of international treaties, contravening the Constitution of Ukraine, shall be possible only after introducing relevant amendments to the Constitution of Ukraine."

According to Art. 9, the Constitution of Ukraine enjoys some extent of supremacy over international law, for it is targeted at the maintenance of the international treaties conformity with the Constitution. Consequently, Art. 9 forbids the conclusion of international treaties contradicting the Constitution, which is permissible only upon relevant amendments to the Constitution. Understanding of international law as subordinate to the Constitution belongs to the less controversial points and has been thus accepted. ${ }^{8}$ Even the Constitutional Court of Ukraine in its recent practice rejected the overall supremacy of international treaties in national legal order. A separate opinion delivered in 2004 concerning the constitutionality of the Law on higher education indicates that the constitution of Ukraine establishes neither general supremacy of international law, nor the superiority of international treaties over national law. ${ }^{9}$ The court is rather in a position to recognize treaties as subordinate to the Constitution's provisions.

A similar position was taken by the Supreme Court of Ukraine. In its guidelines of 1996 for the lower courts 'Application of constitution of Ukraine during justice

8 К. Савчук, 'Шляхи вдосконалення конституційно-правового регулювання застосування норм міжнародного права у внутрішньому правопорядку України' (2014) 3 Український часопис міжнародного права 70 [K. Savchuk, 'Means of improvement of Constitution's regulation on application of international law in domestic law' (2014) 3 Ukrainian Journal of International Law 70]. В. Скоромоха, 'Окремі питання імплементації норм міжнародного права і конституційна юрисдикція України' (2002) 1 Український часопис міжнародного права 6 [V. Skoromoha, 'Specific issues of international law implementation and Ukraine's constitutional jurisdiction' (2002) 1 Ukrainian Journal of International Law 6].

9 Case 14-рп (Constitutional Court, 7 July 2004). Є. Звєрєв, Тлумачення міжнародних договорів начіональними судами: європейський досвід та українська практика, Дис. на здобуття наук ступ. канд. юрид. наук. - 12.00.01 - теорія та історія держави і права; історія політичних і правових вчень. - К., 2015 [Y. Zveriev, 'Interpretation of treaties by national courts: European and Ukrainian practice' (DPhil thesis, Kyiv-Mohyla Academy 2015)]. 
administration, the court just reaffirmed the subordination of international treaties to the Constitution and also highlighted the supremacy of international treaties, consented by the parliament, over national laws.

Commonly, Art. 18 of Ukraine's Constitution refers to foreign policy. The very core of the article is built around the compliance with the generally recognized principles and norms of international law in Ukraine's foreign policy. The provision reads: "The foreign political activity of Ukraine shall be aimed at ensuring its national interests and security by maintaining peaceful and mutually beneficial co-operation with members of the international community in compliance with the generally acknowledged principles and norms of international law."

Both articles are objects of domestic academic scrutiny, foremostly, the scope of Art. 9 and its relation to international law. Even though the majority of modern constitutions bluntly deal with the relation with international treaties, generally, the position of other sources of international law isn't precisely determined and safeguarded by constitutional provisions. Some of the Constitutions refer to other sources of international law as such: the Constitution of Italy, as well as the Constitution of the Russian Federation (to generally recognized principles of international law - Art. $10^{10}$ and Art. $15^{11}$ respectively); the Constitution of the Netherlands (to binding resolutions of international institutions - Arts. 93, 94 ${ }^{12}$ ); Basic Law for the Federal Republic of Germany (general rules of international law - Art. $25^{13}$ ); the Constitution of the Federal Republic of Austria (generally recognized rules of international law - Art. $9^{14}$ ).

Firstly, the sources of international obligations, as it is widely known, are diverse. Their catalogue goes beyond those mentioned in Art. 38 of the Statute of the International Court of Justice of 1945 and includes general principles of international law, binding decisions of international organizations, unilateral acts of States etc. Albeit Art. 9 focuses strictly on international treaties consented to by the Parliament, at the same time it overlooks a great variety of other sources of international obligations. ${ }^{15}$

10 Constitution of Italy, <https://www.senato.it/documenti/repository/istituzione/costituzione_inglese.pdf> (access: 24 July 2016).

11 Constitution of the Russian Federation, <http://www.constitution.ru/en/10003000-01.htm> (access: 24 July 2016).

12 Constitution of the Netherlands, <https://www.government.nl/documents/regulations/2012/ 10/18/the-constitution-of-the-kingdom-of-the-netherlands-2008> (access: 24 July 2016).

13 Basic Law for the Federal Republic of Germany, <https://www.bundestag.de/blob/284870/ ce0d03414872b427e57fccb703634dcd/basic_law-data.pdf> (access: 24 July 2016).

14 Constitution of the Federal Republic of Austria, <http://www.legislationline.org/download/ action/download/id/6052/file/AUSTRIA_Const_2014_en.pdf> (access: 24 July 2016).

15 О. Задорожній, 'Проекти реформування Конституції України і міжнародне право' (2014) 3 Український часопис міжнародного права 29 [O. Zadorozhniy, 'Drafts of Ukraine's constitution and international law' (2014) 3 Ukrainian Journal of International Law 29]; О. Буткевич (n. 3), p. 47; К. Савчук (n. 9), р. 73; В. Денисов, А. Мельник, 'Розвиток правових засад та механізмів верховенства міжнародного прав у внутрішньому праві України' За ред. 
Still some crucial laws, which exist beyond Art. 9, should be taken into consideration. In several instances specific international instruments, other than mentioned in Art. 9, are envisaged in laws. Namely the 1990 Law on police ${ }^{16}$ emphasizes that the 1948 Universal Declaration of Human Rights among others is the legal basis for police action; the 2001 Criminal code of Ukraine, the 2004 Code of civil procedure refer to the generally recognized principles and norms of international law, ${ }^{17}$ along with the 2010 Law on the principles of internal and foreign policy, which in line with its Art. 2 is founded, among others, on generally recognized norms and principles of international law.

Moreover, Art. 9 is confined only to treaties ratified by the parliament, ${ }^{18}$ hence separating them from a large group of treaties concluded by Ukraine without the consent of the parliament. Art. 9 is also mute as to their position in the hierarchy of legal acts in Ukraine. Furthermore, Art. 9 of the Constitution is equally mute about the determination which of laws applies in case of a collision: the international or a national law. ${ }^{19}$ Article 9 is thus characterized by obvious shortcomings, which seemingly are brought about by the neglectful consideration of the 1995 draft of Ukraine's constitution that put forward the concept of the supremacy of international treaties. ${ }^{20}$

The unsatisfactory regulation of the application and effect of international obligations under the provisions of the Constitution is commonly criticized by scholars. ${ }^{21}$ The critique applies at large also to Art. 18, by virtue of which State is bound to comply with generally recognized principles and norms

В. Денисова, Взаємодія міжнародного права з внутрішнім правом України (Юстиніан 2006) [V. Denysov, A. Melnyk, 'Development of legal foundations and mechanisms of rule of international law in domestic law', [in:] V. Denysov (ed.), Interrelation between international law and domestic law of Ukraine (Yustynian 2006)].

16 The law lost its binding force in 2015.

17 В. Денисов, А. Мельник (п. 16), pp. 22-23.

18 О. Мережко, Право міжнародних договорів: сучасні проблеми теорії та практики (Таксон 2002) [O. Merezhko, Law of Treaties: Contemporary problems of theory and practice (Takson 2002)]; Н. Галецька, Форми імплементації міжнародних договорів європейськими державами: порівняльно-правове дослідження, Спеціальність 12.00 .01 - історія та теорія держави і права; історія політичних та правових вчень, Львів 2016 [H. Haletska, 'Types of treaties implementation in European states: Comparative-law research' (DPhil thesis, Lviv National University named after Ivan Franko 2016)]; О. Задорожній (n. 16), p. 32.

О. Мережко (n. 19), pp. 298-299; Д. Третьяков, 'Деякі питання застосування норм міжнародних договорів в Україні' (2002) 3 Український часопис міжнародного права 38 [D. Tretyakov, 'Specific issues of application of treaties in Ukraine' (2002) 3 Ukrainian Journal of International Law 38]; Є. Звєрєв (n. 10), р. 32; О. Задорожній (n. 1), pp. 32-33.

$20 €$ Є. Звєрєв (n. 10), p. 31.

21 В. Буткевич, 'Конституція України: проблеми вироблення нового проекту' (2014) 3 Український часопис міжнародного права 12 [V. Butkevych, 'Constitution of Ukraine: Problems of elaboration of new draft' (2014) 3 Ukrainian Journal of International Law 12]. 
of international law when carrying out its foreign policy. ${ }^{22}$ Probably, the distinction into internal and external State policy, as far as international law is concerned, is currently unjustified.

Another issue discussed by academia is the notion of 'national legislation of Ukraine' endorsed in Art. 9 of the Constitution. Although in 2006 the Court was requested to give official interpretation of Art. 9, including clarification of the status of treaties, ratified by the parliament, it suspended its legal proceedings on the ground of the termination of the 1993 Law on the international treaties of Ukraine. Still separate opinion to the decision urged to carry on proceedings on account of validity of the constitution's Art. $9 .{ }^{23}$ Concurrent divergence of opinions on the substance of Art. 9 hampered the possibility of its integrated interpretation. One group of scholars argued for the narrow perception of Art. 9 as referring only to treaties consented by the parliament. ${ }^{24}$ Some scholars considered inadmissible the notion of 'legislation' in the formula: "international treaties as a part of national legislation", since treaties could be regarded solely as source of law in Ukraine but by no means as legislative act. ${ }^{25}$ They drew attention to Art. 17 of the 2006 Law on the execution of decisions and application of practice of the European Court of Human Rights, which considers ECHR and ECtHR case law as a source of law. ${ }^{26}$ Correspondingly this paves way to the advancing of similar amendments to Art. 9 of the Constitution by substituting 'national legislation' for 'sources of law'.27

Meanwhile, the others suggested understanding Art. 9 as encompassing all categories of treaties concluded by the president or the government. It is maintained that all treaties concluded by Ukraine unconditionally belong to the sources of Ukrainian law, as well as form a part of Ukrainian legislation in spite of Constitution's vague clauses. ${ }^{28}$ This standing was confirmed by the 1994 Law on the procedure of conclusion, execution and denunciation of interagency agreements

22 О. Буткевич, 'Конституційна реформа та проблеми міжнародної договірної практики України' (n. 3), p. 47.

$23 €$ Є. Звєрєв (n. 10), p. 44.

24 Д. Терлецький, Конститучійно-правове регулювання дії міжнародних договорів в Україні (Фенікс 2009) [D. Terletskyy, 'Constitutional regulation of international treaties in Ukraine' (Feniks 2009)].

В. Косович, 'Міжнародне право як засіб вдосконалення нормативно-правових актів України' (2011) 54 Вісник Львівського університету 21 [V. Kosovych, 'International law as a medium of improvement of normative acts in Ukraine' (2011) 54 Bulletin of Lviv University 21]; О. Мережко (n. 19), p. 298.

26 В. Косович, Загальнотеоретичні аспекти удосконалення нормативно-правових актів України, Дис. на здоб. доктора юридичних наук, Спеціальність 12.00 .01 - теорія та історія держави і права; історія політичних та правових учень, Львів 2015 [V. Kosovych, Theoretical aspects of improvement of normative acts of Ukraine (DPhil thesis, Lviv national University named after Ivan Franko 2015)].

27 Ibidem.

28 І.Забокрицький, ‘Проблеми правового статусу міжнароднихдоговорів України усистемі джерел конституційного права України' (2015) 825 Вісник національного університету «Львівська політехніка» 69 [I. Zabokrytskyy, 'Problems of legal status of Ukraine's treaties 
of Ukraine, which requests for the registration of all the treaties by the Ministry of Justice in an unitary registry of normative acts and the 2001 Order of administration and use of unitary State registry of normative acts refers to all treaties of Ukraine without any distinction.

It was expected that the Constitutional Court would elaborate a solution in this respect. ${ }^{29}$ In 1998 its interpretation of the term 'national legislation', however, adhered to the literal wording of Art. 9 maintaining that treaties in force, ratified by the parliament, are a part of national legislation. ${ }^{30}$

At the same time complexity of the existing terminology at any rate is affected by the Ukraine's obligations under the 1969 Vienna Convention on the Law of the Treaties (VCLT). Since Art. 26 (principle pacta sunt servanda) prescribes the performance in good faith in respect towards every treaty in force, which is binding upon the parties, the interpretation of Art. 9 of the Constitution (international treaties ratified by parliament vs. other international instruments) seems to be of minor importance. Art. 26 in conjunction with Art. 27 of the VCLT ("A party may not invoke the provisions of its internal law as justification for its failure to perform a treaty") should prevail over any statements towards the so-called limited scope of recognition of international law in national legal order.

Another topical issue of major concern connected with the notion of 'legislation', in general, and Art. 9, in particular, is the lack of rules delineating the hierarchy between national and international law, particularly in the specification of priority of application. ${ }^{31}$ Between 2008 and 2010 a number of draft laws were consistently elaborated to clarify this issue, however, none of them has been enforced. Interestingly enough, at least several of them distinguished the order of application of international law in national legal order. Clauses provided by draft law No. 1343-1 of $2008^{32}$ and No. 7409 of 2010 suggested superiority of international treaties (regardless of their type and form of consent) over national legislation, apart from the Constitution. Existing foundations of the legislation in this field are aimed at the establishment of basic elements of hierarchy between norms of international and national law. By means of Law on State registration of normative acts adopted by ministries and other executive bodies (1992) a limited

in the system of constitutional sources of Ukraine' (2015) 825 Bulletin of national University Lviv Politechnic 69].

29 Case 12-рп/98 (Constitutional Court, 9 July 1998).

30 В. Косович (n. 27), pp. 331-332.

31 Н. Галецька, Форми імплементації міжнародних договорів європейськими державами: порівняльно-правове дослідження, Спеціальність 12.00 .01 - історія та теорія держави і права; історія політичних та правових вчень, Львів 2016 [H. Haletska, 'Types of treaties implementation in European states: Comparative-law research' (DPhil thesis, Lviv National University named after Ivan Franko 2016)].

32 К. Кармазіна, 'Закон «про систему джерел права України»: актуальність та перспективи' (2008) 9 Вісник Одеського національного університету 101 [K. Karmazina, 'Law on system of sources of law in Ukraine: Actuality and perspectives' (2008) 9 Bulletin of Odessa National University 101]. 
scope of subordination of domestic law to international law is secured. In terms of the law normative acts (decisions, orders, regulations etc.) are not subjected to State registration, if they contravene international treaties of Ukraine ratified by the parliament. Corresponding supervision is carried out by the Ukrainian Ministry of Justice.

Hence, the national legislation of Ukraine reflecting the approaches towards international law is quite ambiguous and vague, which results in perplexity concerning the interpretation of respective clauses within legal regulations. The existing constitutional provisions scarcely encompass State's treatment of international law, sustaining no explicit foundation for interrelation between national and international law. An unreserved recognition of international treaties, ratified by the Parliament, as well as generally recognized principles and norms of international law are insufficient legislative solutions offered by the current Constitution. Moreover, legislation in general doesn't provide for a proper enumeration of implementation of Ukraine's international obligations other than ratified treaties. Altogether, the enacted laws are of controversial character, frequently contravening each other and thus not shaping a uniform pattern. Consequently, legislative amendments are foremost required to ensure coherent ties between laws covering issues of international law. Only on these grounds may the courts afterwards provide appropriate application and interpretation of such laws.

\section{The Application of International Law by the Constitutional Court}

The currently existing intricacy of legislative regulation on the place of international law in Ukrainian law is reflected in the process of its application by domestic courts.

The Constitutional Court abundantly relies on international law. It suffices to mention that within its activities during the period 1997-2014 the court in the majority of cases (82 decisions) referred to the ECHR as well as to the ECtHR and its case law.

Much less frequently did the Court refer to other international instruments, including soft-law resolutions of international organization $s^{33}$ which are not actually

33 М. Гультай, І. Кияниця, 'Норми міжнародного права у практиці конституційного суду України' (2014) 6 Вісник конституційного суду України 82 [M. Hultay, I. Kyjanytsia, 'International law in the Constitutional Court of Ukraine practice' (2014) 6 Bulletin of Constitutional Court of Ukraine 82]; А. Красникова, Имплементация международно-правовых норм в национальное законодательство государств, учебное пособие (Олди-Плюс 2014) [A. Krasnikova, 'Implementation of international law in national law' (Oldi-Plus 2014)]. 
at least on the official level viewed as a part of national legislation. For example, in the case concerning judicial independence ${ }^{34}$ the Court reaffirmed the latter as an integral part of legal status of judges by referring to the 1985 UN General Assembly Basic principles of judiciary, the 1989 UN Economic and Social Council Procedures of effective realization of key principles of judiciary independence. Such soft-law resolutions likely served as a source of inspiration for the Court in order to enhance authority of its judgments.

In the overall practice of the Constitutional Court on international law one can distinguish the following approaches:

Firstly, the Court invokes certain European and international standards dealing with the merits of the relevant case. In the case on freedom of expression ${ }^{35}$ the Court relied on Art. 10 ECHR stating that its application shows that the boundaries of disposable information regarding State officials might be broader than in case of ordinary citizens.

In the death penalty case the Court uncovered the unconstitutionality of Criminal Code provisions on death penalty on the ground of their non-conformity with Art. 3 ECHR and the practice of the ECtHR. ${ }^{36}$ In addition, the Court tackled the issue of the right to life. The wording 'arbitrary deprivation of life', in line with the Court's reasoning, should be understood in terms of inherent right to life, provided for by Art. 6 of the International Covenant on Civil and Political Rights. ${ }^{37}$

In some other cases, concerning, for example, the right to a fair trial case,$^{38}$ the Court in support of its position drew attention both to the ECHR as well as the ECtHR's case law. Taking into consideration the essence of a right to a fair trial, envisaged in Art. $6 \mathrm{ECHR}$, and developed by the ECtHR, as the court observed, the right to execution of court's decision is a part of the right to a fair trial.

Secondly, the Court grounds its decisions on specific provisions of international treaties, which serve as a supplementary reasoning. ${ }^{39}$ For instance, in the case about adversarial proceedings ${ }^{40}$ the Court stressed that equality and non-discrimination amount to principles of Ukraine's Constitution as well as of the International Covenant on Civil and Political Rights of 1966 (Arts. 14 and 26), the Universal Declaration on Human Rights (Arts. 1, 2, and 7), and the ECHR (Art. 14).

\footnotetext{
34 Case 19-рп/2004 (Constitutional Court, 1 December 2004).

37 International Covenant on Civil and Political Rights, <https://treaties.un.org/doc/publication/unts/volume\%20999/volume-999-i-14668-english.pdf> (access: 24 July 2016).

38 Case 11-pп/2012 (Constitutional Court, 25 April 2012).

$39 €$. Звєрєв (n. 10), p. 155.

40 Case 9-рп/2012 (Constitutional Court, 12 April 2012).
} 
Thirdly, the Court addresses and interprets generally recognized principles and norms of international law. This happens arguably less frequently than with reference to other subject matters described in this study.

In the case concerning constitutionality of a local referendum in the Autonomous Republic of Crimea ${ }^{41}$ the Court pointed out that the decision on referendum contradicted not only the relevant provisions of the Constitution but also fundamental principles of sovereignty and territorial integrity, enshrined in international instruments (the UN Charter of 1945, the Helsinki Final Act of 1975). Likewise, in the case concerning the constitutionality of the Declaration of Independence of the Autonomous Republic of Crimea ${ }^{42}$ the Court reaffirmed that the principle of self-determination, according to the UN Charter provisions, excludes any activities aimed at violation of territorial integrity or political unity of sovereign and independent States. Furthermore, population of the Crimea is not entitled to self-determination as it does not constitute a nation in the sense of Constitution's preamble and Art. 1 of the UN Charter.

Another piece of the Court's interpretation worth mentioning relates to customary international law. The Court in its decision (Distribution of products case, $2001)^{43}$ indicated that State's immunity consists in exemption from foreign jurisdiction, except situations dealing with voluntary waiver of such immunity.

When evaluating the congruence of international treaty with constitutional provisions (Rome Statute of the International Criminal Court case, 2001) ) $^{44}$ the Court made reference to Art. 18 of Ukraine's Constitution disclosing the content of generally recognized principles and norms of international law. Consequently, pacta sunt servanda principle, war crimes, crimes against humanity, crime of aggression, genocide, in view of the court, represent customary law which is obligatory irrespective of State's intention of acceding to a given international treaty. Similarly, the Court dealt with the issue of ratification of the treaties through the adoption of laws, which, according to court, do not differ by nature from other laws of Ukraine. ${ }^{45}$ Supplementary to the decision, the Separate Opinion confirmed the supremacy of the Constitution, stipulated by Art. 9 .

Another decision of the Court (Ratification of the European Charter for regional or minority languages case, 2000) ${ }^{46}$ had a collateral connection with international law application. Firstly, the case dealt with the procedure of ratification of international treaties under national law provisions. In this respect, the Court identified a contradiction between the Law on international treaties of Ukraine

41 Case 2-pп/2014 (Constitutional Court, 14 March 2014).

42 Case 3-pn/2014 (Constitutional Court, 20 March 2014).

43 Case 17-рп/2001 (Constitutional Court, 6 December 2001).

44 Case 1-35/2001 (Constitutional Court, 11 July 2001).

45 А.А. Стрижак, Конститучія України в актах Конститучійного Суду України (аналітичний огляд та коментарі) (Iн Юре 2010) [A. Stryzhak, Ukraine's Constitution in the Constitutional Court of Ukraine practice' (analytical review and commentaries) (In Yure 2010)]. 
(1993) and provisions of the Constitution relating to the powers of the head of the Parliament and the head of the State to promulgate laws. ${ }^{47}$

Unlike the Ukrainian Constitutional Court, the courts of general jurisdiction, including the Supreme Court, administrative and commercial courts, are inclined to apply international law in a more limited manner. These courts use international law specifically by referring to international treaties ratified by the parliament that is in line with the terms of Art. 9 of the Constitution. ${ }^{48}$ Nevertheless, some important developments took place recently in this field.

The Supreme Specialized Court of Ukraine in Civil and Criminal Matters endorsed guidelines for lower courts on "Application of international treaties of Ukraine during administering justice by courts" (2014). Even if of soft law character, the document was aimed at harmonization of the application of international law by the courts of general jurisdiction. It underlined concrete aspects of legislation in force. In particular, all international treaties of Ukraine notwithstanding the form of the granted consent are to be considered by courts as a part of domestic law. This immensely contributed to the overriding of existing confinements of Art. 9 of the Constitution. Furthermore, the courts may refer to the resolutions and decisions of international organizations, specialized bodies etc. The Guidelines also referred to the merits of direct application of international treaties, explicitly focusing on human rights international instruments. In line with paragraph 14 of the Guidelines, the Treaties envisaging human rights and fundamental freedoms are subject to application by courts as provisions bearing a direct effect.

\section{Conclusions}

Thus, the practice of international law application by Ukrainian domestic courts is far from consistent. The Constitutional Court acting in the interpretative authority visibly plays the principal role in the process. Its reasoning is firmly rooted in international law, which is often regarded as a pillar for proper reasoning. Yet, the practice of other courts is less inspiring on account of their jurisdictional limit of ratified treaties only. Slight signals of probable progress in this area emerged recently (Supreme Specialized Court of Ukraine guidelines), yet its prospective still remains unclear, particularly in the light of unstable legal environment.

47 Г. Галущенко, Питання міжнародного приватного права у міжнародних договорах України про правову допомогу (Юстиніан, 2005) [H. Halushchenko, 'Issues of international private law in Ukraine's treaties on legal assistance' (Yustynian 2005)]. 


\section{Bibliography}

\section{Case law}

\section{Constitutional Court}

12-рп/98 (9 July 1998)

11-рп/1999 (29 December 1999)

9-pп/2000 (12 July 2000)

1-35/2001 (11 July 2001)

17-рп/2001 (6 December 2001)

8-рп/2003 (10 April 2003)

14-рп/2004 (7 July 2004)

19-рп/2004 (1 December 2004)

9-рп/2012 (12 April 2012)

11-рп/2012 (25 April 2012)

2-рп/2014 (14 March 2014)

3-рп/2014 (20 March 2014)

\section{References}

\section{Books}

Галецька Н., Форми імплементації міжнародних договорів європейськими державами: порівняльно-правове дослідження, Спеціальність 12.00 .01 - історія та теорія держави і права; історія політичних та правових вчень, Львів 2016 [Haletska H., Types of treaties implementation in European states: Comparative-law research (DPhil thesis, Lviv National University named after Ivan Franko 2016)]

Галущенко Г., Питання міжнародного приватного права у міжнародних договорах України про правову допомогу (Юстиніан 2005) [Halushchenko H., Issues of international private law in Ukraine's treaties on legal assistance (Yustynian 2005)]

Денисов В., Мельник А., 'Розвиток правових засад та механізмів верховенства міжнародного прав у внутрішньому праві України', Взаємодія міжнародного права з внутрішнім правом України (Юстиніан 2006) [Denysov V., Melnyk A., 'Development of legal foundations and mechanisms of rule of international law in domestic law', [in:] Denysov V. (ed.), Interrelation between international law and domestic law of Ukraine (Yustynian 2006)]

Звєрєв Є., Тлумачення міжнародних договорів національними судами: європейський досвід та українська практика, Дис. на здобуття наук ступ. канд. юрид. наук. - 12.00 .01 - теорія та історія держави і права; історія політичних і правових вчень. - К., 2015 [Zveriev Y., 'Interpretation of treaties by national courts: European and Ukrainian practice' (DPhil thesis, Kyiv-Mohyla Academy 2015)] 
Косович В., Загальнотеоретичні аспекти удосконалення нормативно-правових актів України, Дис. на здоб. доктора юридичних наук. спеціальність 12.00 .01 - теорія та історія держави і права; історія політичних та правових учень. - Львів 2015 [Kosovych V., Theoretical aspects of improvement of normative acts of Ukraine (DPhil thesis, Lviv national University named after Ivan Franko 2015)]

Красникова А., Имплементация международно-правовых норм в начиональное законодательство государств (Олди-плюс 2014) [Krasnikova A., Implementation of international law in national law (Oldi-Plus 2014)]

Мережко О., Право міжнародних договорів: сучасні проблеми теорії та практики (Таксон 2002) [Merezhko O., Law of Treaties: contemporary problems of theory and practice (Takson 2002)]

Стрижак А., Конституиія України в актах Конституиійного Суду України (аналітичний огляд та коментарі) (Iн Юре 2010) [Stryzhak A., Ukraine's Constitution in the Constitutional Court of Ukraine practice (analytical review and commentaries) (In Yure 2010)]

Терлецький Д., Конституиійно-правове регулювання дії міжнародних договорів в Україні (Фенікс 2009) [Terletskyy D., Constitutional regulation of international treaties in Ukraine (Feniks 2009)]

\section{Articles}

Барабаш О., Декларація про державний суверенітет Украйни. Історія прийняття, документи, свідчення (Рута 2010) [Barabash O., Declaration of state sovereignty of Ukraine. History of adoption, documents, testimonies (Ruta 2010)]

Буткевич В., 'Конституція України: проблеми вироблення нового проекту' (2014) 3 Український часопис міжнародного права 12 [Butkevych V., 'Constitution of Ukraine: Problems of elaboration of new draft' (2014) 3 Ukrainian Journal of International Law 12]

Буткевич О., 'Конституційна реформа та проблеми міжнародної договірної практики України' (2014) 3 Український часопис міжнародного права 42 [Butkevych O., 'Constitutional reform and problems of Ukraine's treaty practice' (2014) 3 Ukrainian Journal of International Law 42]

Гультай М., Кияниця I., 'Норми міжнародного права у практиці конституційного суду України' (2014) 6 Вісник конституційного суду України 82 [Hultay M., Kyjanytsia I., 'International law in the Constitutional Court of Ukraine practice' (2014) 6 Bulletin of Constitutional Court of Ukraine 82]

Забокрицький I., 'Проблеми правового статусу міжнародних договорів України у системі джерел конституційного права України' (2015) 825 Вісник національного університету «Львівська політехніка» 69 [Zabokrytskyy I., 'Problems of legal status of Ukraine's treaties in the system of constitutional sources of Ukraine' (2015) 825 Bulletin of national University Lviv Politechnic 69]

Задорожній О., 'Проекти реформування Конституції України і міжнародне право’ (2014) 3 Український часопис міжнародного права 29 [Zadorozhniy O., 'Drafts of Ukraine’s constitution and international law' (2014) 3 Ukrainian Journal of International Law 29]

Кармазіна К., 'Закон «про систему джерел права України»: актуальність та перспективи' (2008) 9 Вісник Одеського національного університету 101 [Karmazina K., 'Law on system of sources of law in Ukraine: Actuality and perspectives' (2008) 9 Bulletin of Odessa National University 101] 
Косович В., 'Міжнародне право як засіб вдосконалення нормативно-правових актів України' (2011) 54 Вісник Львівського університету 21 [Kosovych V., 'International law as a medium of improvement of normative acts in Ukraine' (2011) 54 Bulletin of Lviv University 21]

Савчук К., 'Шляхи вдосконалення конституційно-правового регулювання застосування норм міжнародного права у внутрішньому правопорядку України' (2014) 3 Український часопис міжнародного права 70 [Savchuk K., 'Means of improvement of Constitution's regulation on application of international law in domestic law' (2014) 3 Ukrainian Journal of International Law 70]

Скоромоха В., 'Окремі питання імплементації норм міжнародного права і конституційна юрисдикція України' (2002) 1 Український часопис міжнародного права 6 [Skoromoha V., 'Specific issues of international law implementation and Ukraine's constitutional jurisdiction' (2002) 1 Ukrainian Journal of International Law 6]

Третьяков Д., 'Деякі питання застосування норм міжнародних договорів в Україні' (2002) 3 Український часопис міжнародного права 38 [Tretyakov D., 'Specific issues of application of treaties in Ukraine' (2002) 3 Ukrainian Journal of International Law 38]

\section{Other}

Constitution of Italy, <https://www.senato.it/documenti/repository/istituzione/costituzione_inglese. pdf> (access: 24 July 2016)

Constitution of the Russian Federation, <http://www.constitution.ru/en/10003000-01.htm> (access: 24 July 2016)

Constitution of the Netherlands, <https://www.government.nl/documents/regulations/2012/10/18/ the-constitution-of-the-kingdom-of-the-netherlands-2008> (access: 24 July 2016)

Basic Law for the Federal Republic of Germany, <https://www.bundestag.de/blob/284870/ce0d03414872b427e57fccb703634dcd/basic_law-data.pdf> > (access: 24 July 2016)

Constitution of the Federal Republic of Austria, <http://www.legislationline.org/download/action/ download/id/6052/file/AUSTRIA_Const_2014_en.pdf> (access: 24 July 2016)

Declaration on State Sovereignty of Ukraine, <http://zakon2.rada.gov.ua/laws/show/55-12> (access: 24 July 2016)

International Covenant on Civil and Political Rights, <https://treaties.un.org/doc/publication/unts/ volume\%20999/volume-999-i-14668-english.pdf> (access: 24 July 2016) 